\title{
STRATEGI PENGEMBANGAN KAMPUNG 99 PEPOHONAN SEBAGAI DAYA TARIK WISATA EDUKASI DI KOTA DEPOK
}

The Strategy Of Developing Village 99 Trees As An Educational Tourism Attraction In Depok City

\author{
Jody Darmawan, Hindun Nurhidayati
}

Program Studi S1 Pariwisata, Fakultas pariwisata, Universitas Pancasila Jalan Raya Lenteng Agung Timur No.56-80, Srengseng Sawah, Jagakarsa, RT.1/RW.3, RT.1/RW.3, Srengseng Sawah, Jagakarsa, Jakarta Selatan - 12640 Telp. 082231391013

\begin{abstract}
Educational tour or educational tour is a program that combines elements of tourism activities with the content of informal education in it. This program is packaged in such a way to be an annual tourism activity or extracurricular activities that have quality and weight for participants who follow this educational tour, the material to be used in this tour has been adjusted to the weight of participants and what information will be provided. village 99 Trees is one of the objects of educational-based tourism destination that provides tourism activities in the area of forest conservation and nature. The objective of the study was to identify the educational potential of Village 99 area and to develop education development strategy in village 99 area. The method used in this research is qualitative method, data collection with observation, questionnaire and documentation. Data analysis in this study using SWOT analysis.The result of the research is SO's strategy which involves involving local communities in the development of educational tourism. Establishing cooperation with gold dome managers related to tourist management, Maintaining beautiful environmental conditions to keep cool, making group tour packages using fish objects.
\end{abstract}

Keywords: Educational, Tourism Development, Tourism Destination 


\section{PENDAHULUAN \\ Latar Belakang}

Indonesia terkenal sebagai negara yang kaya akan sumber daya alamnya. Meskipun memiliki kekayaan alam yang sangat berlimpah, kesejahteraan rakyat Indonesia masih terbilang rendah. Masih banyak masyarakat Indonesia baik yang tinggal di kota maupun desa hidup dalam taraf kemiskinan. Hal ini disebabkan oleh sulitnya mendapatkan pekerjaan sedangkan kebutuhan hidup semakin tinggi. Ditambah lagi dengan munculnya MEA (Masyarakat Ekonomi ASEAN) yang mempermudah tenaga kerja asing masuk ke Indonesia yang semakin menambah sulit lapangan pekerjaan bagi masyarakat menengah ke bawah. Hal ini menjadi perhatian pemerintah untuk pembangunan melalui sektor pariwisata yang berorientasi pada rakyat sehingga dapat meningkatkan kesejahteraan rakyat.

Dengan peningkatan jumlah kunjungan wisatawan nusantara dan mancanegara yang masuk ke Indonesia sejak tahun 2010 sampai 2014. Menurut Pusdatin Kemenpar dan BPS yang dirilis di situs resmi Kementerian Pariwisata, sejak tahun 2010 sampai 2014 terus mengalami peningkatan jumlah kunjungan. Pada tahun 2010 samapai 2014 wisman yang masuk ke Indonesia sebanyak 7.002.944 meningkat menjadi 9.435.411. Jumlah wisatawan dalam negeri juga mengalami peningkatan. Pusdatin Kemenpar dan BPS mencatat perjalanan yang dilakukan wisatawan nusantara sejak tahun 2009 sampai 2013 mengalami peningkatan walau tidak signifikan, yaitu sebanyak 229.731 menjadi 250.036 .

Kota Depok merupakan salah satu kota yang juga memiliki potensi wisata. Kota ini memiliki daya tarik yang tidak kalah dengan daerah lainnya baik wisata alam, budaya maupun kuliner. Di Kota Depok masih sedikit suatu obyek wisata yang mengangkat program berbasis wisata edukasi. Untuk itu Kampung 99 Pepohonan merupakan salah satu tempat wisata yang menggunakan konsep wisata edukasi di Kota Depok. Tujuan mendirikan tempat wisata ini adalah untuk mengasah kemampuan motorik serta membekali anak agar lebih mengenal lingkungan alam yang ada di sekitarnya.

Wisata edukasi merupakan konsep wisata yang menerapkan pendidikan informal tentang suatu pengetahuan kepada wisatawan yang berkunjung ke suatu daya tarik wisata.Di tempat tersebut pengunjung dapat melakukan kegiatan wisata dan belajar dengan metode yang menyenangkan. Melalui edutainment maka proses pembelajaran dapat lebih mudah dimengerti dan diingat karena metodenya yang menyenangkan. Wisata edukasi atau edutourism adalah suatu program dimana wisatawan berkunjung ke suatu lokasi wisata dengan tujuan utama untuk memperoleh pengalaman pembelajaran secara langsung di daya tarik wisata tersebut (Rodger, 1998:28). Menurut Rahmawati (2013) program wisata edukasi dapat berupa ekowisata (ecotourism), wisata sejarah (heritage tourism), desa wisata, wisata komunitas dan pertukaran siswa antar institusi pendidikan (student exchange).

Menurut Ankomah dan Larson (2000) pariwisata pendidikan atau edu-tourism mengacu pada setiap program dimana peserta melakukan perjalanan sebagai sebuah kelompok dengan tujuan utama terlibat dalam pengalaman belajar secara langsung terkait dengan lokasi. Pengembangan wisata edukasi dapat sejalan dengan kegiatan positif dengan mengembangkan wisata minat khusus yaitu wisata edukasi. Tentu dalam perkembangannya wisata edukasi tidak terlepas dari sebuah daerah tujuan wisata yang memiliki aspek sebagai wahana penambah wawasan seperti museum, agrowisata dan lain sebagainya.

\section{Tentang Kampung 99 Pepohonan}

Kampung 99 Pepohonan diharapkan menjadi salah satu tujuan utama bagi para wisatawan baik dalam maupun luar negeri saat berkunjung ke Kota Depok. Konsep yang ditawarkan oleh Kampung 99 ini bertema wisata edukasi. Tempat ini memiliki beberapa program untuk menarik dikunjungi, salah satunya yaitu The Young Greens. Yaitu paket wisata edukasi yang dikemas sesuai dengan tumbuh kembang anak mulai dari permainan di taman, outbound, belajar mengenal ternak sapi serta kelas angklung.

Dalam upaya meningkatkan jumlah kunjungan wisatawan di Kampung 99 Pepohonan diperlukan strategi salah satunya melalui pengembangan Kampung 99 Pepohonan sehingga dapat memiliki nilai jual yang tinggi. Namun pengembangan Kampung 99 Pepohonan harus dilakukan tanpa melanggar prinsip kelestarian lingkungan yang tercermin dalam atraksi- atraksi wisata yang ditawarkan. Kondisi jumlah 
pengunjung Kampung 99 Pepohonan selama ini dapat dilihat dari table berikut:

Tabel 1.1 Jumlah Pengunjung Kampung 99 Pepohonan Sumber: Laporan Tahunan Kampung 99 Pepohonan 20142017 (diolah)

\begin{tabular}{|c|c|c|c|c|}
\hline \multirow{2}{*}{ Bulan ke } & \multicolumn{4}{|c|}{ Jumlah Pengunjung } \\
\cline { 2 - 5 } & $\begin{array}{c}\text { Tahun } \\
2014\end{array}$ & $\begin{array}{c}\text { Tahun } \\
2015\end{array}$ & $\begin{array}{c}\text { Tahun } \\
2016\end{array}$ & $\begin{array}{c}\text { Tahun } \\
2017\end{array}$ \\
\hline 1 & 469 & 654 & 511 & 1048 \\
\hline 2 & 198 & 121 & 55 & 145 \\
\hline 3 & 85 & 59 & 132 & 108 \\
\hline 4 & 220 & 175 & 115 & 222 \\
\hline 5 & 98 & 188 & 176 & 169 \\
\hline 6 & 284 & 423 & 321 & 433 \\
\hline 7 & 368 & 336 & 409 & 517 \\
\hline 8 & 477 & 251 & 380 & 430 \\
\hline 9 & 563 & 570 & 327 & 139 \\
\hline 10 & 280 & 110 & 70 & 115 \\
\hline 11 & 174 & 144 & 122 & 73 \\
\hline 12 & 542 & 597 & 641 & 1344 \\
\hline Total & & & & \\
Pengunjung & 3758 & 3628 & 3259 & 4743 \\
\hline$\%$ & $37.58 \%$ & $36,28 \%$ & $32,59 \%$ & $47,43 \%$ \\
\hline
\end{tabular}

Atraksi wisata edukasi yang ditawarkan Kampung 99 Pepohonan sebagian besar sudah selaras dengan prinsip kelestarian lingkungan, seperti atraksi Mind Map, Super Memory, Brain Gym, Brain Games, Planting, Vertical Garden, Reptiles \& Mammals Corner, Fishing, Outbond, pengetahuan Global Warming dan sebagainya. Namun hal tersebut harus dibarengi dengan pengelolaan yang baik, sehingga dapat memberikan kepuasan bagi pengunjung dan diharapkan semakin banyak wisatawan yang berkunjung di tempat ini. Penelitian ini bertujuan untuk mengidentifikasi potensi pendidikan yang menyenangkan ( wisata edukasi) sebagai strategi pengembangan kawasan Kampong 99 Pepohonan.

\section{Rumusan Masalah}

Berdasarkan latar belakang penelitian di atas, maka rumusan masalah pada penelitian ini adalah:

1. Bagaimana kondisi Existing komponen pariwisata di Kampung 99 Pepohonan.

2. Bagaimana strategi pengembangan wisata edukasi untuk mengembangkan Kampung 99 Pepohonan.

\section{Tujuan Penelitian}

Sesuai rumusan masalah yang tertulis diatas, berikut adalah tujuan dari dilaksanakanya penelitian:

1. Mengidentifikasi kondisi Existing komponen pariwisata di Kampung 99 Pepohonan.

2. Menganalisis Strategi pengembangan wisata edukasi dikampung 99 Pepohonan.

\section{TINJAUAN PUSTAKA}

\section{Teori Pengembangan Pariwisata}

Menurut Undang-Undang Republik Indonesia Nomor 18 Tahun 2002 tentang Sistem Nasional Penelitian, Pengembangan, dan Penerapan Ilmu Pengetahuan dan Teknologi Pengembangan adalah kegiatan ilmu pengetahuan dan teknologi yang bertujuan memanfaatkan kaidah dan teori ilmu pengetahuan yang telah terbukti kebenarannya untuk meningkatkan fungsi, manfaat, dan aplikasi ilmu pengetahuan dan teknologi yang telah ada, atau menghasilkan teknologi baru. Pengembangan secara umum berarti pola pertumbuhan, perubahan secara perlahan (evolution) dan perubahan secara bertahap.

Menurut Seels \& Richey (Alim Sumarno,

2012) pengembangan berarti proses menterjemahkan atau menjabarkan spesifikasi rancangan kedalam bentuk fitur fisik. Pengembangan secara khusus berarti proses menghasilkan bahan-bahan pembelajaran.

\section{Daya Tarik/Atraksi Wisata}

Pariwisata memiliki daya tarik wisata yang dimanfaatkan oleh suatu kawasan atau destinasi menarik wisatawan. Daya tarik wisata ini yang menjadi alasan wisatawan mengunjungi suatu destinasi. Undang-Undang Republik Indonesia No. 10 Tahun 2009 mendefinisikan Daya Tarik Wisata adalah segala sesuatu yang memiliki keunikan, keindahan, dan nilai yang berupa keanekaragaman kekayaan alam, budaya, dan hasil buatan manusia yang menjadi sasaran atau tujuan kunjungan wisatawan.

\section{Atraksi}

Mill and Morrison (1992) dalam bukunya "The Tourism System" menjabarkan bahwa pengertian atraksi (attractions) adalah suatu tempat yang memiliki kemampuan untuk menarik orang lain dan bertujuan untuk memenuhi kebutuhan rekreasi pengunjung.

Victor T.C. Middleton dalam Yoeti, 2010 membagi daya tarik wisata yakni: 
1. Natural Attractions

Yaitu daya tarik wisata yang bersifat alamiah dan terdapat secara bebas yang dapat dilihat dan disaksikan setiap waktu.

2. Build Attractions

Yaitu bangunan-bangunan dengan arsitektur kuno, jembatan, rumah-rumah ibadah, gedunggedung perkantoran bekas penjajahan Belanda, dll.

3. Cultural Attractions

Peninggalan lama, petilasan, bekas kerajaan, candi, museum.

4. Traditional Attractions

Yaitu tata cara hidup suatu etnis, masyarakat terasing, adat istiadat, festival kesenian, foljlore suatu bangsa.

5. Sport Events

Yaitu aktivitas yang berkaitan dengan dunia olahraga, baik ikut berpartisipasi dalam kegiatan olahraga tersebut, maupun hanya datang menyaksikan pertandingan berlangsung.

6. Attractive Spontanee

Segala sesuatu yang terdapat di DTW yang merupakan daya tarik wisata, sebagai alasan mengapa wisatawan tertarik datang berkunjung ke DTW tersebut.

\section{Aksesibilitas}

Menurut Jhon Black mengatakan bahwa aksesbilitas merupakan suatu ukuran kenyamanan atau kemudahan dalam mencapai lokasi dan hubungannya satu sama lain mudah atau sulitnya lokasi tersebut dicapai melalui transportasi (Leksono,Dkk 2010). Aksesbilitas adalah konsep yang luas dan fleksibel. Kevyn lync mengatakan aksesbilitas adalah masalah waktu dan juga tergantung pada daya tarik dan identitas rute perjalanan (Talav Era,2012).

Derek Halden Concultancy (DHC,2000) mencirikan pemahaman aksesbilitas dalam tiga pertanyaan: siapa/dimana, apa, bagaimana

- Siapa atau dimana orang itu beradaaksesbilitas adalah bagian dari orang atau tempat

- Apa peluang yang akan dicapai-fungsi tata guna lahan, aktivitas didalamnya, atau sumber daya (termasuk orang-orang yang memungkinkan orang itu memenuhi kebutuhan mereka.

- Bagaimana faktor-faktor yang memisahkan orang-orang dengan tempat seperti jarak, waktu, biaya, informasi dan faktor-faktor lain yang bertindak sebagai pencegah atau hambatan untuk mengakses suatu tempat.

\section{Amenitas}

Amenitas adalah fasilitas yang dimiliki daerah tujuan wisata, meliputi akomodasi, usaha pengolahan makanan, transportasi, rekreasi dan lain-lainOka A. Yoeti (2002:211) dalam Jurnal Penelitian Edwin Fiatiano (2012) "Mengemas Produk Pariwisata Pada Daerah Tujuan Wisata". Amenitas adalah fasilitas yang dimiliki daerah tujuan wisata, meliputi akomodasi, usaha pengolahan makanan, transportasi, rekreasi dan lain-lain.

\section{Teori Wisata Edukasi}

Rodger(1998) dalam bukunya Managing Educational Tourism menyatakan bahwa edutourism atau Pariwisata Pendidikan dimaksudkan sebagai suatu program di mana peserta kegiatan wisata melakukan perjalanan wisata pada suatu tempat tertentu dalam suatu kelompok dengan tujuan utama mendapatkan pengalaman belajar secara langsung terkait dengan lokasi yang dikunjungi. Program Pariwisata Pendidikan dapat berupa ekowisata (ecotourism), wisata warisan (heritage tourism), wisata pedesaan / pertanian (rural/farm tourism), wisata komunitas (community tourism) dan pertukaran siswa antar institusi pendidikan (student exchanges). Pariwisata pendidikan tidak akan memiliki makna apabila tidak dikelola dengan baik. Terdapat beberapa unsur dalam pengelolaan wisata pendidikan, meliputi:

1. Demografi wisata pendidikan, motivasi, persepsi dan menghasilkan perilaku perjalanan.

2. Pribadi dampak wisata pendidikan yang dihasilkan dari pengalaman.

3. Keterkaitan faktor dalam atau di antara kelompok-kelompok yang terlibat.

4. Pengelolaandan pemasaran pariwisata untuk pendidikan.

5. Sumber daya untuk pendidikan Pariwisata.

6. Tujuan dan dampak Yang Berkaitan dengan pariwisata pendidikan.

7. Ketertarikan faktor dalam atau diantara kelompok-kelompok.

Wisata edukasi atau wisata pendidikan adalah suatu program yang menggabungkan unsur 
kegiatan wisata dengan muatan pendidikan informal di dalamnya. Program ini dikemas sedemikian rupa menjadi kegiatan wisata tahunan atau kegiatan ekstrakurikuler yang memiliki kualitas dan berbobot bagi peserta yang mengikuti wisata pendidikan ini, materi yang akan digunakan dalam wisata ini telah disesuaikan dengan bobot peserta wisata dan informasi apa saja yang akan diberikan (Hapsari, 2010). Wisata pendidikan merupakan bentuk kegiatan wisata yang menunjang tujuan studi para pengunjung (Arifin dalam Dinata, 2009).Lebih lanjut, Suwantoro (2002) menyatakan bahwa wisata pendidikan merupakan suatu perjalanan wisata dengan maksud untuk memberikan gambaran, studi perbandingan ataupun pengetahuan mengenai bidang kerja yang dikunjungi.

Program Wisata Edukasi

Wisata yang bermuatan pendidikan dapat ditemui pada ekowisata (ecotourism), wisata sejarah (heritage tourism), desa wisata, wisata komunitas dan pertukaran siswa antar institusi pendidikan (student exchange) (Rahmawati, 2013).

\section{Jenis-Jenis wisata Edukasi}

Menurut Soemarno (2008), terdapat 4 jenis wisata Edukasi, diantaranya adalah:

a. Wisata Edukasi Science/ Ilmu pengetahuan wisata edukasi Science atau Ilmu pengetahuan adalah wisata edukasi yang berbasis kepada pendidikan ilmu pengetahuan.

b. Wisata Edukasi Sport/ Olahraga Wisata edukasi Sport atau Olahraga adalah wisata edukasi yang berbasis kepada pendidikan secara fisik atau olahraga.

c. Wisata Edukasi Culture/ kebudayaan wisata Edukasi Culture atau kebudayaan diantaranya pendidikan dalam bidang seni, adat istiadat dan lain-lain yang berhubungan dengan kebudayaan.

d. Wisata Edukasi Agro bisnis wisata Edukasi Agrobisnis merupakan wisata edukasi yang berbasis kepada pendidikan argo, pertanian atau pertenakan yang juga merupakan suatu bisnis dari suatu perusahaan.

\section{Teori AIDA (Attraction, Interest, Desire, Action)}

AIDA merupakan singkatan sederhana yang telah dibuat lama sebagai pengingat dari empat tahap proses penjualan AIDA singkatan dari Attention, interest, Desire, Action ini merupakan model cukup sederhana dan dapat digunakan sebagai pedoman. Dalam komunikasi pemasaran perlu dirumuskan tujuan yang ingin dicapai dari proses komunikasi pemasar yang akan dilakukan. AIDA merupakan aebuah konsep yang dimana dalam sebuah pemasaran sangatlah memegang peranan penting.

\section{Attention}

Dalam Attention ini seorang pemasar haruslah mampu membuat sebuah media informasi agar mengandung daya tarik bagi konsumen. membuat suatu pernyataan yang mengungkap perhatian orang, membuat kata atau gambar yang powerful yang bisa menarik perhatian orang berhenti dan memperhatikan isi pesan berikutnya. Kotler\&Amstrong (2006:500) mengemukakan bahwasanya daya tarik (Attention) haruslah mempunyai tiga sifat : (1) Harus bermakna (meaningful), menunjukkan manfaat-manfaat yang membuat produk lebih diinginkan atau lebih menarik bagi konsumen, (2) Pesan harus dapat dipercaya (Believeable), konsumen percaya bahwa produk tersebut akan memberikan manfaat seperti yang dijanjikan dalam pesan, (3) Distinctive, bahwa pesan iklan lebih baik dibanding iklan merek pesaing.

\section{Interest}

Interest adalah langkah setelah seorang pemasar mampu untuk membuat sebuah media informasi tersebut agar dapat mengandung daya tarik bagi konsumen, seorang pemasar haruslah memikirkan sebuah media informasi agar dapat mengandung minat bagi calon pelanggan atau konsumennya tersebut. Kebanyakan media informasi yang buruk melalaikan dalam melakukan tahapan ini, ditahap inilah sebenarnya target atau konsumen bersedia memberikan waktunya untuk membaca pesan dari pemasar lebih detail. Bangun minat pembaca dengan memberikan janji solusi atas masalah atau harapan mereka. Cara yang baik adalah dengan menjelaskan fitur dan benefit jangan hanya memberikan fakta dan fitur saja, dan merasa pembaca akan berfikir sendiri benefit yang akan di dapat, tetapi menjelaskan dengan sejelasnya benefitnya tersebut untuk meningkatkan interst. 
3. Desire

Selanjutnya langkah yang harus dilakukan oleh seorang pemasar ialah memunculkan keinginan untuk mencoba atau memiliki, dimana dalam tahapan ini pemasar haruslah jeli atau pintar membaca target konsumen dalam tahapan ini. Langkah ini membuktikan bahwa seorang pemasar mampu memberikan solusi yang tepat dalam sebuah keputusan bagi konsumen. Dalam tahap ini khalayak telah mempunyai motivasi untuk memiliki produk sampai pada tahap ini, Seorang pemasar telah berhasil menciptakan kebutuhan calon pembeli sudah mulai goyah dan emosinya mulai tersentuh. Namun demikian timbul perlawanan dalam diri calon pembeli berupa keraguan, Benarkah produk atau jasa yang bersangkutan memberikan sesuatu seperti yang dijanjikan iklannya.

4. Action

Dalam tahapan yang paling pusat ini seorang pemasar haruslah sudah mengarah pada tindakan untuk membeli dalam tahapan actionini menjelaskan langkah apa yang dilakukan oleh seorang pemasar dalam menginginkan untuk pembaca atau konsumen melakukan keputusan untuk membeli. Membimbing pembaca atau konsumen karena pembaca atau konsumen akan bertindak jika seorang pemasar menjelaskan langkahlangkahnya dan kadang juga perlu diinformasikan masalah harga untuk tindakan tersebut. Dalam tindakan action ini yaitu yang salah satu upaya terakhir untuk mmbujuk calon pembeli agar sesegera mungkin melakukan tindakan pembelian atau bagian dari proses itu juga dengan memilih kata yang tepat agar calon pembli atau konsumen melakukan respon yang sesuai dengan yang diharapkan adalah suatu pekerjaan yang sangat sulit. Harus digunakan kata perintah agar calon pembeli bergerak.

\section{Pengertian Analisis SWOT}

Menurut Rangkuti (2015) analisis SWOT adalah identifikasi berbagai faktor secara sistematis untuk merumuskan strategi perusahaan.Analisis ini didasarkan pada logika yang dapat memaksimalkan kekuatan dan peluang, namun secara bersamaan dapat meminimalkan kelemahan dan ancaman. Mengacu pada definisi yang dijelaskan oleh Rangkuti, analisis SWOT hanya berpatokan pada 4 elemen dari 2faktor yaitu kekuatan dan kelemahan yang merupakan faktor internal dan peluang dan ancaman yang merupakan faktor external.

Dewasa ini, analisis SWOT juga sering digunakan dalam mengembangkan destinasi atau daya tarik pariwisata. Dengan menganalisis 4 elemen tersebut diharapkan dapat menemukan strategi pengembangan yang sesuai dengan daya tarik wisata tersebut. Pada lingkup pariwisata, strength yang dimaksud adalah kelebihan apa yang dimiliki oleh suatu kawasan/destinasi/daya tarik wisata yang dapat dioptimalkan untuk pengembangan. Sedangkan weaknesses yang dimaksud dalam lingkup pariwisata adalah kekurangan atau kelemahan yang dimiliki oleh kawasan/destinasi/daya tarik wisata yang kemungkinan dapat menghambat pengembangan pariwisata. Jika dari faktor external, opportunities yang dimaksud dalam lingkup pariwisata adalah seberapa besar peluang suatu kawasan/destinasi/daya tarik wisata untuk dapat bersaing dan memenuhi permintaan pasar. Sedangkan threats yang dimaksud adalah ancaman yang kiranya akan mengganggu pengembangan suatu kawasan/destinasi/daya tarik wisata, contohnya seperti adanya kebijakan politik yang merugikan, isu terorisme, dan bahkan adanya destinasi/daya tarik wisata lain yang sejenis di sekitar mampu menjadi ancaman.

\section{Matriks SWOT}

Menurut Rangkuti (2015), Matriks SWOT dapat menggambarkan secara jelas bagaimana peluang dan ancaman eksternal yang dihadapi perusahaan dapat disesuaikan dengan kekuatan dan kelemahan yang dimilikinya. Matriks ini

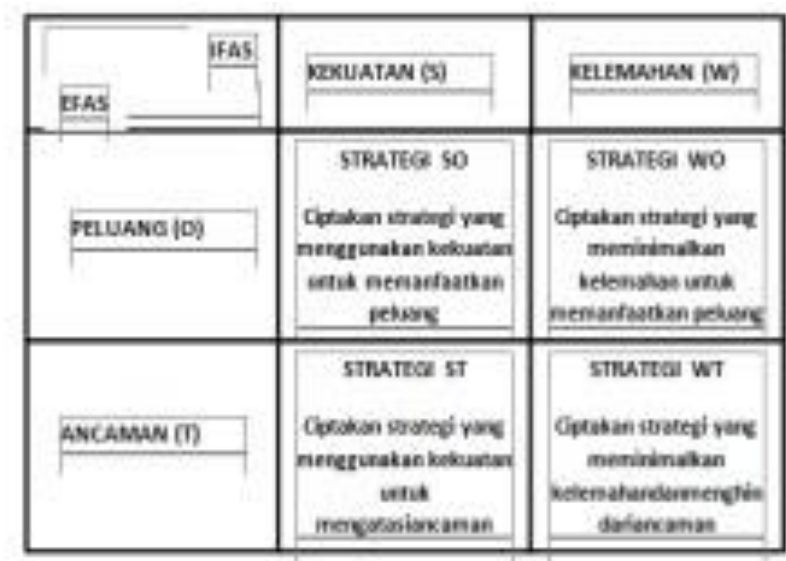

dapat menghasilkan empat set kemungkinan altenatif strategis. 
Berikut ini adalah keterangan dari matriks SWOT diatas :

1. Strategi SO (Strength and Oppurtunity). Strategi ini dibuat berdasarkan jalan pikiran perusahaan, yaitu dengan memanfaatkan seluruh kekuatan untuk merebut dan memanfaatkan peluang sebesar - besarnya.

2. Strategi ST (Strength and Threats). Strategi dalam menggunakan kekuatan yang dimiliki perusahaan untuk mengatasi ancaman.

3. Strategi WO (Weakness and Oppurtunity). Strategi ini diterapkan berdasarkan pemanfaatan peluang yang ada dengan cara meminimalkan kelemahan yang ada.

4. Strategi WT (Weakness and Threats).

Strategi ini berdasarkan kegiatan yang bersifat defensif dan berusaha meminimalkan kelemahan yang ada serta menghindari ancaman.

\section{Desain Penelitian}

Desain penelitian ini adalah dengan menggunakan pendekatan deskriptif kualitatif. Metode-metode dalam pendekatan kualitatif sering digunakan untuk melihat lebih dalam suatu fenomena sosial termasuk di dalamnya kajian terhadap ilmu pendidikan, manajemen dan administrasi bisnis, kebijakan publik, pembangunan ilmu hukum.Pada dasarnya metode penelitian kualitatif ditujukan untuk penelitian yang bersifat mengamati kasus. Dengan demikian, proses pengumpulan dan analisis data bersifat kasus pula (Indrawan \& Yaniawti, 2014).

Pada peneltian kali ini peneliti menggunakan metode studi kasus dalam pendekatan deskriptif kualitatif. Creswell (1997 dalam Indrawan \& Yaniawati, 2014) menjelaskan studi kasus adalah sebuah eksplorasi mendalam mengenai sebuah sistem yang terkait. Bisa juga aktivitas, kejadian, proses ataupun individu, berdasarkan pengumpulan data yang ekstensif.

\section{Jenis dan Sumber Data}

Jenis data pada penelitian ini terbagi menjadi dua, yaitu data primer dan data skunder. Data primer adalah data yang didapat melalui proses observasi dan wawancara mendalam pada responden yang memiliki kompetensi terkait lokasi tersebut. Data sekunder adalah data yang diperoleh melalui data di luar observasi dan wawancara, seperti publikasi pemerintah, berita di media, majalah, dan sebagainya. Sumber data pada penelitian ini adalah informan dan kawasan. Informan merupakan sumber dari data yang dihimpun dengan cara melakukan wawancara mendalam. Sedangkan kawasan merupakan sumber dari data yang akan dihimpun melalui observasi.

\section{Teknik Pengumpulan Data}

Pengumpulan data pada penelitian ini menggunakan pendekatan kualitatif.Teknik pengumpulan data dan informasi yang lazim digunakan dalam pendekatan kualitatif, adalah kuisioner (Indrawan \& Yaniawati, 2014:133).

Peneliti akan melakukan observasi di lingkungan Kawasan Kampung 99 Pepohonan terkait dengan pengembangan Wisata Edukasi, khususnya melihat potensi yang dimiliki kawasan tersebut sebagai daya tarik wisata berbasis Wisata Edukasi. Kuisioner akan dilakukan kepada pihak yang terlibat dalam pengelolaan kawasan dan masyarakat lingkungan sekitar terkait pengembangan kawasan tersebut sebagai daya tarik wisata berbasis wisata edukasi.

\section{HASIL DAN PEMBAHASAN}

\section{Gambaran Umum Lokasi Penelitian}

Pada awalnya kawasan ini didirikan bukan sebagai tempat wisata, melainkan sebagai kompleks hunian keluarga yang ramah lingkungan. Kampung 99 Pepohonan terdapat 18 kepala keluarga dengan total penghuni sebanyak 135 orang. Kampung ini memproduksi sendiri seluruh kebutuhan pangan sehari-hari seperti beras organik, daging, pupuk, roti tanpa pengawet, keju, susu, madu, sayur-mayur, yoghurt, dan ikan. Selain kebiasaan serta budaya masyarakatnya mengkonsumsi makanan secara alami, tetapi juga membangun hubungan sosial dengan yang cukup erat. Hubungan antar tetangga dibangun atas dasar keterbukaan dan kolektivisme untuk terus mempertahankan kebiasaan mereka serta untuk pelestarian lingkungan. Dalam menjaga konservasi ekosistem kampung ini menerapkan pembuangan limbah rumah tangga dengan merancang "sistem satu laundry, satu dapur dan satu sumur". Misalnya kegiatan mencuci pakaian dipusatkan di rumah seorang penghuni yang dekat dengan Sungai Pesanggrahan. Kegiatan memasak dipusatkan di rumah penduduk yang gemar memasak dengan 
menggunakan kayu bakar yang diperoleh dari ranting atau dahan pohon yang berguguran.

Dalam kampung ini semua penghuni bebas untuk mengembangkan ide, minat dan potensi sehingga membuat kehidupan di kampung kecil ini semakin lengkap. Karena memiliki udara yang sejuk serta menarik sehingga masyarakat luas mengenal Kampung 99 Pepohonan, akhirnya mulai tahun 2005 Kampung 99 Pepohonan dibuka untuk umum. Kampung wisata 99 juga menjual berbagi macam produk hasil pertanian dan kebun mereka seperti yoghurt, beras organik, daging, madu, cuka apel, ikan dan sayuran bahkan hasil lading serta ternak mereka juga dijual di pasar tradisional Depok.

Lokasi Kampung 99 Pepohonan tepatnya di Jl. KH. Muhasan II, Kelurahan Meruyung, Kecamatan Limo, Depok, KM 14 dari tol Fatmawati. Tempat ini adalah sebuah hunian penduduk yang dibangun dengan konsep pertanian terpadu dan tempat tinggal yang menyatu dengan alam juga sekaligus menjadi wisata keluarga bagi penduduknya serta masyarakat di luar Kampung 99 Pepohonan.

\section{Potensi Kampung 99 Pepohonan Depok Sebagai Wisata Edukasi}

\section{A. Atraksi Dan Wisata Edukasi}

Atraksi wisata merupakan suatu hal yang dapat dijadikan sebagai penarik wisatawan datang ke suatu destinasi. Menurut Mill and Morrison (1992) dalam bukunya "The Tourism System" menjabarkan bahwa pengertian atraksi (attractions) adalah suatu tempat yang memiliki kemampuan untuk menarik orang lain dan bertujuan untuk memenuhi kebutuhan rekreasi pengunjun

Kampung 99 Pepohonan sementara ini memiliki atraksi wisata berupa tour perternakan sapi dan kambing dimana pengunjung bisa memberikan makan kepada ternak tersebut. Ada juga beberapa kandang hewan lain misalnya babi, monyet dan rusa yang dapat menjadi atraksi edukasi menarik bagi anak-anak. Menurut pokdarwis selaku pihak pengelola wisata Kampung 99 Pepohonan menjelaskan bahwa kampong ini memiliki 2000 sapi dan 1500 kambing. Selain itu Kampung 99 Pepohonan juga memiliki dua kolam renang yaitu kolam renang sedang dan kolam renang yang dangkal. Atraksi lain yang ditawarkan adalah ATV jika ingin berkeliling kampung.

\section{Amenitas Dan Kelembagaan}

Menurut Inskeep (1991) amenitas termasuk Akomodasi, rumah makan, retail, toko cinderamata, fasilitas penukaran uang, biro perjalanan, pusat informasi wisata dan fasilitas kenyamanan lainnya. Cooper (dalam Suwena dan Widyatmaja, 2010), menegaskan bahwa secara umum pengertian fasilitas (amenities) adalah segala macam prasarana dan sarana yang diperlukan oleh wisatawan selama berada di daerah tujuan wisata. Kelembagaan yang dimaksud adalah kelembagaan yang diperlukan untuk membangun dan mengelola kegiatan wisata, termasuk perencanaan tenaga kerja dan program pelatihan dan pendidikan (Inskeep, 1991). Inskeep juga menjelaskan bahwa peran

kelembagaan pada suatu destinasi ialah menyusun strategi marketing dan program promosi, menstrukturisasi organisasi wisata sektor umum dan swasta, peraturan dan perundangan yang berhubungan dengan wisata, menentukan kebijakan penanaman modal bagi sektor publik dan swasta, mengendalikan program ekonomi, lingkungan, dan sosial kebudayaan.

Sehingga kesimpulannya bahwa amenitas merupakan fasilitas wisata yang harus ada di suatu daya tarik wisata untuk memberikan pelayanan serta kebutuhan wisatawan. Fasilitas pendukung merupakan elemen penting dalam pengembangan destinasi wisata. Memang bukan menjadi elemen utama tetapi sangat berpengaruh pada pertimbangan wisatawan ketika ingin memutuskan destinasi mana yang ingin mereka kunjungi. Menurut Sunaryo (2013), fasilitas pendukung adalah fasilitas yang digunakan oleh wisatawan, seperti bank, telekomunikasi, rumah sakit dan sebagainya. Fasilitas Pendukung menurut Inskeep (1991) dan Sunaryo (2013) Infrastruktur yang dimaksud adalah penyediaan air bersih, listrik, drainase, saluran air kotor, telekomunikasi (seperti telepon, telegram, telex, faksimili, dan radio)Ketersediaan fasilitas pendukung yang digunakan oleh wisatawan, seperti bank, telekomunikasi, pos, rumah sakit, dan sebagainya. Tanggapan Hasil Wawancara Untuk fasilitas pendukung di sekitar kampung sudah banyak fasilitas-fasilitas masyarakat yang dibangun pemerintah. Fasilitas pendukung juga c 
ukup lengkap misalnya Kampung 99 Pepohonan juga dekat dengan rumah sakit besar, dan juga ATM salah satu bank ternama. Fasilitas pendukung sudah cukup lengkap, maksudnya pembangunan yang dilakukan pemerintah sejauh ini akan memudahkan

\begin{tabular}{|c|c|c|}
\hline $\begin{array}{l}\text { Kotler dan } \\
\text { Keller } \\
(2006: 500) \\
\text { tentang } \\
\text { model AIDA }\end{array}$ & $\begin{array}{c}\text { Tanggapan } \\
\text { terkait } \\
\text { Keputusan } \\
\text { Berkunjung } \\
\text { dari } \\
\text { narasumber }\end{array}$ & Pemaknaan \\
\hline 1. Perhatian & $\begin{array}{l}\text { Belum mampu } \\
\text { menarik perhatian } \\
\text { wisatawan, karena } \\
\text { masih sedikit } \\
\text { wisatawan yang } \\
\text { belum mengetahui } \\
\text { kampung } 99 \\
\text { pepohonan. }\end{array}$ & $\begin{array}{l}\text { Wisata edukasi } \\
\text { yang terdapat di } \\
\text { kampung } 99 \\
\text { Pepohonan } \\
\text { banyak yang dapat } \\
\text { digali tetapi } \\
\text { kurangnya } \\
\text { informasi atau } \\
\text { promosi yang } \\
\text { dipasarkan } \\
\text { sehingga banyak } \\
\text { orang tua atau } \\
\text { wisatawan yang } \\
\text { belum mengetahui } \\
\text { kampung } 99 \\
\text { pepohonan }\end{array}$ \\
\hline 2. Ketertarikan & $\begin{array}{l}\text { Belum mampu } \\
\text { meningkatkan } \\
\text { ketertarikan } \\
\text { wisatawan } \\
\text { terhadap wisata } \\
\text { Edukasi, karena } \\
\text { kenyataanya } \\
\text { masih banyak } \\
\text { yang datang } \\
\text { hanya liat liat } \\
\text { keindahan dan } \\
\text { kesejukan } \\
\text { alamnya saja }\end{array}$ & $\begin{array}{l}\text { Belum terlihat } \\
\text { masyarakat } \\
\text { memiliki } \\
\text { ketertarikan } \\
\text { terhadap wisata } \\
\text { Edukasi. Terbukti } \\
\text { masih banyak } \\
\text { wisatawan datang } \\
\text { lihat lihat setelah itu } \\
\text { pulang karena } \\
\text { tempat wisata } \\
\text { yang kurang } \\
\text { menarik perhatian } \\
\text { dan terlihat sepi }\end{array}$ \\
\hline 3. Keinginan & $\begin{array}{l}\text { Keinginan } \\
\text { wisatawan yang } \\
\text { kurang } \\
\text { mengetahui } \\
\text { tentang adanya } \\
\text { wisata edukasi di } \\
\text { dalam Kampung } \\
\text { 99 Pepohonan. }\end{array}$ & $\begin{array}{l}\text { Kurangnya } \\
\text { sosialisasi wisata } \\
\text { edukasi kepada } \\
\text { masyarakat dan } \\
\text { wisatawan yang } \\
\text { datang jadi } \\
\text { keinginan } \\
\text { masyarakat yang } \\
\text { berkunjung ke } \\
\text { kampung } 99 \\
\text { masih kurang. }\end{array}$ \\
\hline Volume $7 I$ & $\begin{array}{l}\text { Belum } \\
\text { memaksimalka } \\
\mathrm{n} \\
\text { partisipasiTinda } \\
\text { kan masyarakat } \\
\text { setempat } \\
\text { secara } \\
\text { luas dalam } 1 \text { p9ses } \\
\text { opengantbifan }\end{array}$ & $\begin{array}{l}\text { Masyarakat belum } \\
\text { diajak berperan aktif } \\
\text { secara penuh } \\
\text { sehingga banyak } \\
\text { juga } \\
\text { masyarakat yang } \\
\text { tidak perduli } \\
S S N: 2339-1987 \\
\end{array}$ \\
\hline & keputusan. & $\begin{array}{l}\text { dengan lingkungan } \\
\text { Kampung } \\
99 \text { Pepohonan . }\end{array}$ \\
\hline
\end{tabular}

wisatawan Kampung 99. Hasil Observasi Di Lapangan Di sekitar Kampung 99 terdapat Rumah Sakit, Pos Polisi, ATM, Bank, Klinik. Lokasi Kampung 99 juga sudah dialiri listrik, terdapat air bersih, sungai untuk drainase sehingga tidak banjir. Pemaknaan Fasilitas pendukung untuk wisata Kampung 99 sudah tersedia dengan cukup baik. Begitupun dengan infrastruktur lain seperti air bersih, listrik, saluran air kotor, drainase, dsb.

\section{B. Aksesibilitas}

Aksesibilitas merupakan salah satu aspek yang harus diperhatikan dalam pengembangan pariwisata, karena ini adalah cara wisatawan untuk mengakses daya tarik tersebut dalam hal ini Kampung 99 Pepohonan. Dalam pengertian ini, aksesibilitas adalah segenap fasilitas dan moda angkutan yang memungkinkan dan memudahkan serta membuat nyaman wisatawan untuk mengunjungi suatu destinasi (Sunaryo, 2013).Menurut Cooper (dalam Suwena dan Widyatmaja, 2010), aksesibilitas merupakan jalan masuk atau pintu masuk utama ke daerah tujuan wisata. Bandara, pelabuhan, dan segala macam jasa transportasi lainnnya menjadi akses yang penting dalam pariwisata.

\section{Hasil Observasi}

\section{A. Atraksi dan Daya tarik wisata berdasarkan model AIDA}

Berdasarkan hasil penelitian dan teori keputusan berkunjung wisata edukasi, Kampung 99 Pepohonan belum mampu memanfaatkan semua potensi yang dimilikinya untuk dijadikan daya tarik wisata edukasi. Sehingga semenatara ini hanya peternakan sapi, kolam renang, dan ATV saja yang dijadikan atraksi wisata. Padahal lokasi tersebut memiliki banyak potensi wisata edukasi lain-lain yang mampu menarik wisatawan untuk datang menikmati alam dan kesejukan Kampung 99 Pepohonan. Pokdarwis selaku lembaga yang mengelola kawasan serta yang paling dekat dengan masyarakat mampu mengajak masyarakat untuk memanfaatkan peluang dan potensi yang ada untuk dikembangkan sebagai tempat wisata edukasi untuk menarik wisatawan berkunjung di Kampung 99 Pepohonan.

\section{B. Hasil Observasi Amenitas Dan}


Kelembagaan Di Kampung 99 Pepohonan

Amenitas Menurut Inskeep

(1991)

Akomodasi, rumah makan, retail, toko cinderamata, fasilitas penukaran uang, biro perjalanan, pusat informasi wisata dan fasilitas kenyamanan lainnya. Dari hasil observasi dan wawancara kampong ini agak lambat dalam mengembangkan amenitasnya. Ketersediaan amenitas masih kurang memadai misalnya, restoran dibangun sangat sederhana oleh warga. Adapun warung kelontong lokasinya cukup jauh kira-kira $500 \mathrm{~m}$ dari lokasi Kampung 99 Pepohonan. Pemaknaan dari aspek amenitas Kampung 99 Pepohonan masih belum siap menjadi daya tarik wisata untuk menarik pengunjung lebih banyak.
1) Hasil Observasi terkait Amenitas dan kelembagaan sesuai dengan Keputusan berkunjung wisata Edukasi berdasarkan Model AIDA

Tabel 4.2

\begin{tabular}{|l|l|l|}
\hline $\begin{array}{l}\text { Kotler dan Keller (2006:500) } \\
\text { tentang model AIDA }\end{array}$ & $\begin{array}{l}\text { Tanggapan terkait Keputusan } \\
\text { Berkunjung dari narasumber }\end{array}$ & \multicolumn{1}{|c|}{ Pemaknaan } \\
\hline 1. Perhatian & $\begin{array}{l}\text { Belum mampu menarik perhatian } \\
\text { wisatawan, karena masih sedikit } \\
\text { rumah makan dan fasilitas } \\
\text { amenitas dan kelembagaan di } \\
\text { Kampung 99 Pepohonan. }\end{array}$ & $\begin{array}{l}\text { kurangnyaPengembangan pada } \\
\text { amenitas dan kelembagaan untuk } \\
\text { wisatawan di kampung 99 } \\
\text { pepohonan. }\end{array}$ \\
\hline 2. Ketertarikan & $\begin{array}{l}\text { Tidak mampu meningkatkan } \\
\text { ketertarikan wisatawan terhadap } \\
\text { amenitas dan kelembagan, } \\
\text { karena kenyataanya masih } \\
\text { banyak yang datang hanya untuk } \\
\text { bersantai tidak untuk mengetahui } \\
\text { informasi dan bagaimana strategi } \\
\text { promosi yang ada di Kampung 99 } \\
\text { Pepohonan. }\end{array}$ & $\begin{array}{l}\text { Belum terlihat masyarakat } \\
\text { memiliki ketertarikan terhadap } \\
\text { amenitas dan kelembagaan. } \\
\text { Terbukti masih banyak } \\
\text { tidak ingin mengagali informasi di } \\
\text { kelembagaan kampung 99 } \\
\text { Pepohonan. karena tempat wisata } \\
\text { yang kurang menarik perhatian } \\
\text { dan terlihat sepi }\end{array}$ \\
\hline 3. Keinginan & $\begin{array}{l}\text { Banyaknya Keinginan wisatawan } \\
\text { yang kurang mengetahui tentang } \\
\text { adanya fasilitas amenitas } \\
\text { kelembagaan di dalam Kampung } \\
\text { 99 Pepohonan. }\end{array}$ & $\begin{array}{l}\text { Kurangnya sosialisasi mengenai } \\
\text { fasilitas amenitas dan } \\
\text { kelembagaan kepada masyarakat } \\
\text { dan wisatawan yang datang jadi } \\
\text { keinginan masyarakat yang } \\
\text { berkunjung ke kampung 99 } \\
\text { masih kurang. }\end{array}$ \\
\hline 4. Tindakan & $\begin{array}{l}\text { Belum memaksimalkan } \\
\text { partisipasiTindakan masyarakat } \\
\text { setempat untuk menggali } \\
\text { informasi mengenai amenitas dan } \\
\text { kelembagaan dalam proses } \\
\text { observasi terkait proses } \\
\text { pengambilan keputusan. }\end{array}$ & $\begin{array}{l}\text { Masyarakat belum berperan } \\
\text { secara aktif sehingga banyak juga } \\
\text { masyarakat yang tidak perduli } \\
\text { dengan keadaan pusat informasi, } \\
\text { tempat makan dan kelembagaan } \\
\text { Kampung 99 Pepohonan } .\end{array}$ \\
\hline
\end{tabular}




\section{Hasil Observasi Aksesibilitas Di Kampung 99 Pepohonan}

Aksesibilitas Menurut Inskeep (1991) meliputi transportasi akses dari dan menuju tempat wisata, transportasi internal yang menghubungkan atraksi utama kawasan wisata dan kawasan pembangunan, termasuk semua jenis fasilitas dan pelayanan yang berhubungan dengan transportasi darat, laut, dan udara. Jalan menuju Kampung 99 Pepohonan sudah cukup bagus. Selain itu Kota Depok sudah memiliki terminal dan Stasiun kereta yang terintegrasi sehingga akses menuju kampung ini cukup mudah untuk dicapai baik menggunakan kendaraan pribadi maupun angkutan umum. Angkutan kota sudah banyak yang melalui Kampong 99 Pepohonan.
Pemaknaan Dari segi aksesibilitas, Kampung 99 Pepohonan sudah terbantu dengan adanya Stasiun Kereta yang menghubungkan kota-kota di Jabodetabek. Stasiun tersebut pun terintegrasi dengan Terminal Kota Depok sehingga memudahkan wisatawan langsung menaiki angkutan umum menuju Kampung 99 Pepohonan. Begitu pun dengan wisatawan yang menggunakan kendaraan pribadi akan sangat mudah menemukan lokasi Kampung 99 Pepohonan. Sehingga disimpulkan komponen aksesibilitas Kampung 99 Pepohonan sudah cukup siap.

1) Hasil Observasi terkait Aksesbilitas sesuai dengan Keputusan berkunjung wisata Edukasi berdasarkan Model AIDA

Tabel 4.3

\begin{tabular}{|c|c|c|}
\hline $\begin{array}{l}\text { Kotler dan Keller (2006:500) } \\
\text { tentang model AIDA }\end{array}$ & $\begin{array}{l}\text { Tanggapan terkait } \\
\text { Keputusan Berkunjung dari } \\
\text { narasumber }\end{array}$ & Pemaknaan \\
\hline 1. Perhatian & $\begin{array}{l}\text { Belum mampu menarik } \\
\text { perhatian } \\
\text { wisatawan, karena masih } \\
\text { sedikit wisatawan yang belum } \\
\text { mengetahui akses untuk pergi } \\
\text { ke kampung } 99 \text { pepohonan. }\end{array}$ & $\begin{array}{l}\text { Aksesbilitas yang terdapat di } \\
\text { kampung 99 Pepohonan } \\
\text { Masih kurang karena jalan } \\
\text { menuju ke kampung } 99 \\
\text { tersebut jauh dari jalan } \\
\text { utama. }\end{array}$ \\
\hline 2. Ketertarikan & $\begin{array}{l}\text { Belum mampu meningkatkan } \\
\text { ketertarikan wisatawan } \\
\text { mengenai aksesbilitas, karena } \\
\text { untuk akses kendaraan } \\
\text { sebenarnya mudah tetapi } \\
\text { untuk masuk ke area } \\
\text { Kampung masih terlalu. }\end{array}$ & $\begin{array}{l}\text { Belum terlihat masyarakat } \\
\text { memiliki ketertarikan } \\
\text { mengenai Aksesbilitas. } \\
\text { Karena akses untuk masuk ke } \\
\text { kampung belum terjangkau } \\
\text { dengan Angkutan umum. }\end{array}$ \\
\hline 3. Keinginan & $\begin{array}{l}\text { Keinginan wisatawan yang } \\
\text { kurang mengetahui imengenai } \\
\text { Aksesibilitas Kampung } 99 \\
\text { Pepohonan. }\end{array}$ & $\begin{array}{l}\text { Kurangnya sosialisasi kepada } \\
\text { masyarakat dan wisatawan } \\
\text { yang datang mengenai akses } \\
\text { untuk pergi ke Kampung } 99 \\
\text { Pepohonan jadi keinginan } \\
\text { masyarakat yang } \\
\text { berkunjungmasih kurang. }\end{array}$ \\
\hline 4. Tindakan & $\begin{array}{l}\text { Belum memaksimalkan } \\
\text { partisipasiTindakan } \\
\text { masyarakat setempat secara } \\
\text { luas mengenai hal } \\
\text { akasesibilitas dalam proses } \\
\text { pengambilan keputusan. }\end{array}$ & $\begin{array}{l}\text { Masyarakat belum diajak } \\
\text { berperan aktif secara penuh } \\
\text { sehingga banyak juga } \\
\text { masyarakat yang tidak perduli } \\
\text { dengan Akses yang ada di } \\
\text { Kampung } 99 \text { Pepohonan . }\end{array}$ \\
\hline
\end{tabular}


Sumber : Jurnal diolah

\section{SIMPULAN DAN SARAN Simpulan}

Potensi edukasi di Kampung 99 Pepohonan sangat berpotensi untuk dikembangkan lebih baik lagi. Selain dapat menikmati pemandangan dan suasana alaminya, wisatawan juga dapat melakukan berbagai macam kegiatan wisata seperti camping, fotografi, outbound dan juga shooting serta bermain ATV, Berenang. Untuk kondisi exsiting kampung 99 Pepohonan kondisi saat ini pengelola dalam proses mengurus izin ke Pemkot Depok karena adanya perubahan fungsi Kampung 99 Pepohonan menjadi objek wisata edukasi. Namun kesepakatan secara lisan antara Kampung 99 Pepohonan dengan pemerintah kota bidang lingkungan hidup sejak dahulu sebagai upaya untuk mempertahankan lokasi sebagai Ruang Terbuka Hijau (RTH).

Berdasarkan hasil data yang telah dianalisis selama penelitian dengan menggunakan matriks IE dan SWOT, strategi pengembangan wisata berbasis edukasi di Kampung 99 Pepohonan yang dapat dikembangkan sebagai potensi daya tarik wisata adalah strategi SO yang berisikan melibatkan masyarakat lokal dalam pengembangan wisata edukasi, menjalin kerja sama dengan pengelola kubah emas terkait pengelolaan wisatawan, Menjaga kondisi lingkungan yang asri agar tetap sejuk serta membuat paket wisatawan grup dengan menggunakan objek ikan.

\section{Saran}

Untuk memperbanyak jumlah kunjungan, Kampung 99 Pepohonan dapat bekerjasama dengan pihak pengelola Masjid Kubah Emas. Dan berdasarkan hasil penelitian yang dilakukan dengan analisis SWOT dan matriks IE terdapat saran terhadap pengembangan edukasi untuk Kampung 99 Pepohonan yaitu strategi SO yang berisikan Melibatkan masyarakat lokal dalam pengembangan wisata edukasi, Menjalin kerja sama dengan pengelola kubah emas terkait pengelolaan wisatawan, Menjaga kondisi lingkungan yang asri agar tetap sejuk, membuat paket wisatawan grup dengan menggunakan objek ikan.

\section{DAFTAR PUSTAKA}

Augusty,Ferdinand. 2006. Metode Penelitian Manajemen: Pedoman Penelitian untuk skripsi, Tesis dan Disertai Ilmu Manajemen. Semarang: Universitas Diponegoro.

Berita Utama Kementerian Pariwisata. (Online).(www.kemenpar.go.id). Diakses 2 Februari 2017.

Chafid,F. 2002. Perencanaan Kepariwisataan Alam Bandung. Bandung; Universitas Pendidikan Indonesia

Daryanto. 1997. Kamus Bahasa Indonesia

Lengkap, Surabaya: Apollo

Endar.K. d. 2000. Metode penelitian dalam bidang kepariwisataan.

Gaffar,Vanessa. 2011. Pengaruh Strategi Positioning Museum Terhadap Kunjungan Wisata Edukasi Di Kota Bandung . Tourism and Hospitality Essential Journal.Vol.1 No. 1.

Hermantoro.H.2015. Kepariwisataan, Destinasi Pariwisata, Produk Pariwisata. Depok: CV ADITRI

Indrawan, R \& Yaniawati, P. 2014.Metedeologi PENELITIAN Kuantitatif, Kualitatif, dan campuran untuk manajemen, Pembangunan, Dan Pendidikan. Bandung: REFIKA ADITAMA

Inskeep, Edward. 1991. Tourism Planning: An integreted and suistainable Approach. Van Nostrand Reinhold. New York, Inc.

Kartini,T. 2011. Pengembangan Model Pendidikan Pariwisata berbasis Agrowisata Perkebunan Kopi dikabupaten Jember. Vol. 1 No. 1.

Kotler, Philip 2006. Manajemen Pemasaran: Analisis Perencanaan Implementasi dan kontrol. Jakarta: PT.Prehalindo

Oktaviani, Shinta.2015. Skripsi Strategi Pengembangan Atraksi Wisata Budaya Di Museum Indonesia TMII sebagai sumber pembelajran jakarta.

Pitana.IG. 2009.Pengantar Ilmu Pariwisata Yogyakarta: Penerbit Andi

Putranto,A.R. 2012. Strategi Pengembangan Objek Wisata Loko Tour dan Objek wistata sebagai Edukasi dikabupaten Blora Vol. 2 No. 1. 
Profil Kampung 99 Pepohonan

(Online).(www.kampung99pepohonan.go.id).

Diakses 12Oktober 2017.

Rangkuti, F. 2016. Analisis SWOT: Teknik

Membedah Kasus Bisnis. Jakarta; Gramedia Pustaka Utama

Rofiq.A, Arifin.Z, Wilopo. 2012.Pengaruh Penerapan AIDA (Attention, Interest, Desire, Action)Terhadap keputusan Pembelian. (survei pada pembeli kartu perdana IM3 dilingkungan Mahasiswa Fakultas Ilmu Administrasi Universitas Brawijaya Angkatan 2012.). Vol 1 No 3.

Sugiarto, Endar dan Kusmayadi.2000.Metedologi Penelitian Dalam Bidang Kepariwisataan Jakarta.

Sugiyono. 2009. Metode Penelitian Kuantitatif

Kualitatif dan RND. Bandung: Alfabeta.

Suwena, Widyamatja, 2010. Pengatahuan

Dasar Ilmu Pariwisata. Denpasar.

Syam, Nina W. 2010. Pariwisata Di Indonesia. Bandung: Bandung

Yoeti, Oka A. 1983. Pengantar Ilmu

Pariwisata. Bandung: Angkasa.

Yoeti, O. A. 2002. Perencanaan \& Pengembangan Pariwisata.

Yoeti, O. A. 2010. Dasar-dasar Pengertian Hospitaliti dan Pariwisata.

Yoeti, O. A. .2010.Ekonomi Pariwisata introduksi informasi dan implementasi. 